\title{
Tóth KaTA
}

\section{BÜNTETETT ELŐÉLETŰEKKEL KAPCSOLATOS SZTEREOTÍPIÁK}

Tudat alatt szüntelen foglalkozunk embertársainkkal, értékeljük őket a velük folytatott interakciók során, itéletet alkotunk róluk magunkban. Ez pozitív és negatív következményekkel egyaránt jár, hiszen a bennünk élő sztereotípiák leegyszerűsítik a valóságot, ezáltal segítik a további információfeldolgozást, de implikált elméleteink torzítják is a bennünk kialakuló képet, részrehajlást és hibákat eredményeznek. Az aktiválódott sztereotípiák olyan láncreakciót indíthatnak be, amely belőlünk és másokból is a sztereotípiát megerősítő viselkedéseket vált ki.

A nemek szerinti kategorizálás az emberekkel való érintkezésünknek már olyannyira részévé vált, hogy legtöbbször még tudatában sem vagyunk annak, hogy ez alapján ítélünk. Sok szempontból osztályozhatjuk a körülöttünk levőket, de egyik besorolási mód sem annyira jelentős, mint a maga a nem. Williams és Best kutatása alapján (1982, idézi az egyik ilyen sztereotípiát Smith - Mackie 2006: 286) a férfiakat agresszívebbnek, kevésbé érzékenynek tekintik a nőknél.

Elő́téleteket vált ki az a másikról való ismeret is, ha tisztában vagyunk azzal, hogy ítélték már szabadságvesztésre őt, függetlenül attól, hogy annak mi volt az oka (Fehér 1999). Egy személyről, aki már követett el bűncselekményt, nagyobb mértékủ agresszivitást feltételeznek, mint a büntetlen elóéletűekről.

Kutatásom során arra voltam kíváncsi, a nemekre és a büntetett előéletűekre vonatkozó sztereotípiák milyen mértékben torzítják egymást.

\section{A VIZSGÁLATI MÓDSZER}

Vizsgálatom két részből tevődött össze. Mindegyik alapját egy általam készített történet szolgálta. Ennek négy verziója készült el, de csak a szereplő személyében különböztek egymástól. A később megítélendő fiktív célszemélyek két független változó variációi voltak: büntetett/büntetlen, férfi/nő.

Előfeszítéses módszert alkalmaztam, vagyis a történet előtt, az instrukcióban megadtam, kiről olvashatnak a kísérleti személyek a továbbiakban. Mindegyik szereplőről tudni lehetett, hogy 34 éves, magyar, férfi vagy nő, továbbá az instrukció legvégén szerepelt, ha büntetett elóéletű volt. Erre azért volt szükség, hogy 
bizonyos sémákat aktiváljak a helyzet kontextusa által. Az előfeszítés képes a sztereotípiákat automatikusan, a tudatosság megkerülésével előhívni (Atkinson 2005).

A történetek megírásakor a LCM-modell1 ${ }^{1}$ alapján (Semin - Fiedler 1992, idézi Antal 2008) szigorúan leíró igéket használtam (pl. megpofoz, megsimogat, ad, mond valamit stb.), kerültem az olyan állításokat, amik nyíltabban utalnak a szereplő valamilyen vonására, szándékára vagy mentális állapotára.

A történet 3 epizódból állt.

Az első részében egy agresszív tett szerepelt, mivel az elsőbbségi hatás alapján az elsőként kapott információk játsszák az összbenyomás kialakításában a döntő szerepet (Atkinson 2005: 691). A cselekedet egyértelműen szándékos volt, de a szituáció leírása során törekedtem arra, hogy a megfigyelő mind a helyzeti tényezőknek, mind a szereplőnek tulajdoníthassa a cselekvés okát. Ennek az az oka, hogy ha az agresszív tett szándékos, tehát valóban a szereplő agressziójáról van szó, és nem a véletlenről, akkor lehet csak felmérni az LCM rendszerével, hogy a különböző sztereotípiáknak mennyire része az agresszivitás mint vonás.

A történet következő részében egy proszociális epizód került bemutatásra: a szereplő hazafelé menet pénzt adott egy metró-aluljáróban egy piszkos, szakadt ruhájú embernek, aki megállította őt, és mondott neki valamit. Az olvasók fantáziájára bíztam, ki és miért kapott tőle ekképp segítséget.

A történetet egy gondoskodást sugalló epizód zárta. Amikor a fiktív szereplő hazaért, látta, hogy a lánya nem tud elaludni. Vitt be neki egy pohár tejet és megsimogatta a fejét, majd mindketten nyugovóra tértek.

Vizsgálatom első részében az instrukcióban hangsúlyoztam, hogy figyelmesen olvassák el a történetet. Elmondtam, hogy lesz egy következő alkalom is, amikor erről még szó esik, de azt nem árultam el, hogy emlékezeti vizsgálat következik majd. A történet elolvasása után egy tulajdonságlistát kaptak Máriáról, illetve Béláról. Az egyes állítások után jelölniük kellett egyetértésük mértékét egy ötfokú skálán, hogy szerintük mennyire jellemző rá az adott tulajdonság. Ez több célt is szolgált: az így kapott statisztikai adatok egyrészt egy empirikus vizsgálat alapját képezték, másrészt pedig ezek végiggondolásakor rögzült bennük valamelyest a történet.

A vizsgálat második részét pedig egy emlékezetvizsgálat alkotta. Bartlett (1985) szerint az attitűdjeink jelentősen befolyásolják a felidézést. A célszemély egy napjá-

I A Linguistic Category Model, vagyis a LCM-modell modell megalkotásakor a szerzők (Semin - Fiedler, I992, idézi Antal, 2008) abból indultak ki, a különböző nyelvi kategóriák eltérő implicit jelentéssel rendelkeznek, tehát egy esemény leírásakor a beszélőnek lehetősége van a konkrét-absztrakt dimenzió különböző pontjain elhelyezkedő nyelvi eszközökkel kifejezni az állítmányt. Az állítmányt leíró cselekvést jelentő ige a leginkább konkrét, a legkevesebb értelmezést magában rejtő megfogalmazási mód, az állítmányt értelmező vagy állapotot jelentő ige ennél már absztraktabb, a sztereotipizálás pedig akkor a legnyilvánvalóbb, ha az egyén jelzőt használ állítmányként. 
ban pozitív és negatív viselkedések egyaránt szerepeltek, és a leírások nyitva hagyták a történeteket, így lehetségessé vált ezáltal a sztereotípiának megfelelő kiegészítés. A történet exponálása és felidézése között mindegyik esetben egy hét telt el. Ez nem elég hosszú időtartam ahhoz, hogy elfelejtsék, miről szólt a szöveg, de elegendő ahhoz, hogy csak a történet fö mozzanatai maradjanak meg az emlékezetükben, saját képzeletük által kiszínezve.

A négy történettel egy pécsi iskola négy gimnáziumi osztályát kerestem fel. Az eredeti célkitűzésem az volt, hogy mindegyik változatot legalább 30 diák elolvassa és kitöltse utána a teszteket. Ezt sajnos nem tudtam teljesíteni, mivel a vizsgálati személyek azok a diákok lehettek csak, akik mindkét alkalommal jelen voltak; másrészt az iskolaigazgató tesztfelvétellel szemben támasztott negatív attitűdje miatt meghiúsult a vizsgálat egy része, és más intézménytől kellett segítséget és engedélyt kérnem a kutatásom befejezéséhez.

A vizsgálatban szereplő személyek átlagos életkora 17,59 év. Az első csoport Máriáról, a büntetett elóéletű magyar nőről olvashatott, összesen 18 fö. A 2. csoportba 20 kísérleti személy került. Az ő történetükben Mária mint (büntetlen) 34 éves, magyar nő szerepelt. A 3. csoport csak 13 főből áll, ők Béláról, a büntetett eloéletü, 34 éves, magyar férfiről alkottak véleményt. A 4. csoport létszáma 15, az előfeszítő inger pedig számukra Béla, egy 34 éves, magyar férfi volt. Az így kapott eredmények a kis elemszám (össz. 66 fö) miatt nem tekinthetők reprezentatívnak és nem általánosíthatók, de rálátást nyújtanak a végzős gimnazisták elítéltekkel kapcsolatos, illetve nemi sztereotípiáira.

\section{HIPOTÉZISEK ÉS EREDMÉNYEK}

Hipotéziseim a következők voltak:

- A nemi sztereotípiák szerint a férfiak inkább agresszívek, mint a nők.

- A bűnözőkről alkotott sztereotípiák szerint a bűnelkövetők inkább agresszívek, mint az átlagos emberek.

Azt vizsgáltam, hogy a személypercepció (különböző személyiségvonások és viselkedés-értelmezések) szempontjából a nem vagy a priusz bír nagyobb hatással. Az absztrakció szintje hogyan változik az egyes epizódok során? Mely viselkedéseket milyen mértékben általánosították a vizsgálati személyek a különböző célszemélyek esetében? Ez megfelel-e a személypercepciójuknak (vonásskálák és predikció tekintetében)? 
A tulajdonságlista által nyert adatokat az SPSS 17.0-s verziójával; az emlékezetvizsgálat során kapott történeteket pedig első lépésben az Atlas ti 5.0-s, majd az SPSS 17.0-s verziójával elemeztem.

Az elemzés során két kétértékủ független változót használtam, így 4 csoportra bontottam őket: büntetett nő, büntetett férfi, büntetlen nő és büntetlen férfi; a függő változóként pedig a személyiségpercepció szerepelt, különösképp az agreszszivitás, a proszociális és a gondoskodó viselkedés tekintetében.

Elöször azt vizsgáltam, hogy a tesztben az agresszivitáshoz asszociálható tulajdonságokat a faktoranalízis elkülöníti-e egy külön csoportba, és ha igen, mely tulajdonságok tartoznak ide. A faktoranalízis azonban nem vált be. Ezért korrelációs kapcsolatokat vizsgáltam. Mivel a tulajdonságlistában közvetlenül nem kérdeztem rá a agresszivitásra, a listában szereplő hozzá legközelebb álló tulajdonságból indultam ki, a veszekedősből. Megnéztem, hogy mely tulajdonságokkal áll ez szignifikáns kapcsolatban. Ezek közül kiválasztottam a pozitív előjelủeket, mert ezek mozognak együtt a veszekedés tulajdonságával. A lenti táblázatban látható, hogy a veszekedős tulajdonság megítélése közepes szorosságú kapcsolatban áll a barátságtalan, az idegesítő, a hideg, a felelőtlen, a modortalan és a beképzelt jelzőkkel. Bár az együttérző, a megbízhatatlan, és a beképzelt tulajdonság is szignifikáns kapcsolatban áll vele, de a köztük levő kapcsolat gyenge, így nem vontam be őket a további elemzésbe.

Az első hipotézisem alapján a nemi sztereotípiák szerint a férfiak inkább agreszszívek, mint a nők. Ehhez először átkódoltam az osztályokat a nemük szerint, függetlenül attól, hogy elítéltek voltak-e vagy sem. Így keletkezett az, hogy nőt vagy férfit ítéltek meg. Jelentős eltérés a két nem megitélésében 5\%-os szignifikanciaszinten nincs statisztikailag. Az eredeti hipotézis tehát elvetendő.

A második hipotézisem alapján a bünözőkről alkotott sztereotípiák szerint a bűnelkövetők inkább agresszívek, mint az átlagos emberek. Az alábbi táblázatban jelölt tulajdonságokra kaptam szignifikáns különbségeket a kriminális előélet tekintetében: 
1. táblázat: A gimnazisták által bünelkövetök jellemzésére használt tulajdonságok

\begin{tabular}{|c|c|c|c|}
\hline & & N elemszám & átlag \\
\hline \multirow[t]{3}{*}{ barátságtalan } & büntetett & $3 \mathrm{I}$ & 2,4516 \\
\hline & büntetlen & 35 & $2,57 \mathrm{I} 4$ \\
\hline & Total & 66 & 2,5152 \\
\hline \multirow[t]{3}{*}{ idegesítő } & büntetett & $3 \mathrm{I}$ & $2,5 \mathrm{I} 6 \mathrm{I}$ \\
\hline & büntetlen & 35 & $2,657 \mathrm{I}$ \\
\hline & Total & 66 & 2,5909 \\
\hline \multirow[t]{3}{*}{ hideg } & büntetett & $3 \mathrm{I}$ & 2,7097 \\
\hline & büntetlen & 35 & 2,4857 \\
\hline & Total & 66 & 2,5909 \\
\hline \multirow[t]{3}{*}{ felelötlen } & büntetett & $3 I$ & 3,0000 \\
\hline & büntetlen & 35 & $2,17 \mathrm{I} 4$ \\
\hline & Total & 66 & 2,5606 \\
\hline \multirow[t]{3}{*}{ modortalan } & büntetett & $3 \mathrm{I}$ & 2,9355 \\
\hline & büntetlen & 35 & 2,2000 \\
\hline & Total & 66 & 2,5455 \\
\hline \multirow[t]{3}{*}{ beképzelt } & büntetett & $3 \mathrm{I}$ & 2,3548 \\
\hline & büntetlen & 35 & 2,0857 \\
\hline & Total & 66 & $2,2 \mathrm{I} 2 \mathrm{I}$ \\
\hline \multirow[t]{3}{*}{ veszekedős } & büntetett & $3 \mathrm{I}$ & 3,4194 \\
\hline & büntetlen & 35 & 2,7429 \\
\hline & Total & 66 & 3,0606 \\
\hline
\end{tabular}

Forrás: saját vizsgálat

Vagyis a büntetett előéletűeket felelőtlenebbnek, modortalanabbnak és veszekedősebbnek tartják, mint a büntetlen előéletű személyeket. A hipotézist csak részben sikerült alátámasztanom.

Ezt követően létrehoztam egy aggregátum változót, amelyben az agresszivitás szempontjából lényeges tulajdonságok szerepeltek. Ezek értékelésének átlaga lett az aggregátum változó értéke.

2. táblázat: A megitélt és az itéletet mondó személyek nekem szerinti elkülönitése

\begin{tabular}{l|l|l|l}
\hline Átlag / aggregátum & Osztály & & \\
\hline Nem & Büntetettet ítél & Büntetlent ítél & Végösszeg \\
\hline Féri ítél & 2,53 & 2,53 & 2,53 \\
\hline Nó ítél & 2,88 & 2,37 & $2,6 \mathrm{I}$ \\
\hline Végösszeg & 2,77 & 2,42 & 2,58 \\
\hline
\end{tabular}

Forrás: saját vizsgálat 
A büntetett és büntetlen aggregát megítélése között eltérés van, ezért megvizsgáltam, hogy statisztikailag is eltérőnek minősül-e ez a két átlag, de statisztikailag nem tekinthető szignifikánsnak az eltérés.

Harmadszor voltam kíváncsi, a személypercepció (különböző személyiségvonások és viselkedés-értelmezések) szempontjából a nem vagy a priusz bír nagyobb hatással. Ezt a két tulajdonság négy lehetséges kombinációjának azonos módszerrel történő vizsgálata tárja fel. A kapott eredmények alapján a priusz jobban meghatározó:

3. táblázat: A személyiségpercepció nem és priusz alapján történö vizsgálata

\begin{tabular}{l|l|l|l}
\hline Átlag / aggregátum & OsztályM2 & & \\
\hline osztálym & Büntetettet ítél & Büntetlent ítél & Végösszeg \\
\hline Férfit ítél & $2,8 \mathrm{I}$ & 2,33 & 2,56 \\
\hline Nőt ítél & 2,74 & 2,48 & 2,60 \\
\hline Végösszeg & 2,77 & 2,42 & 2,58 \\
\hline
\end{tabular}

\begin{tabular}{l|l|l|l}
\hline Átlag / aggregátum & nem & & \\
\hline osztálym & Férfi ítél & Nö ítél & Végösszeg \\
\hline Férfit ítél & 2,70 & 2,73 & 2,72 \\
\hline Nöt ítél & 2,60 & 2,68 & 2,66 \\
\hline Végösszeg & 2,64 & 2,70 & 2,68 \\
\hline
\end{tabular}

Forrás: Saját vizsgálat

Végül azt vizsgáltam, az absztrakció szintje hogyan változik az egyes epizódok során. A három különböző viselkedést (vagyis agresszív, proszociális, gondoskodó) milyen mértékben általánosították a vizsgálati személyek a különböző célszemélyek esetében, milyen nyelvi kategória segítségével fejezték ki magukat a felidézéskor? Ez megfelel-e a személypercepciójuknak (vonásskálák és predikció)? Szignifikáns eredményt csak a büntetett férfiak esetén kaptam. Az ő esetükben az agreszszív epizódban a másik 3 csoporthoz képest több absztrakt állítmányt használtak, a proszociális, illetve a gondoskodó epizódban pedig kevesebbet.

\section{DISZKUSSZIÓ}

A vizsgálatom során nem sikerült igazolnom a nemi sztereotípiák létezését. Ez nem jelenti feltétlenül azt, hogy a férfiakat ne tartanák inkább agresszívebbnek, mint a nőket, hiszen számos kutatás (Banaji 2003) támasztja alá e sztereotípia létezését.

A kapott eredmény mindössze arra a négy gimnáziumi osztályra vonatkoztatható, hiszen a kutatásom több szempontból is támadható az adatgyűjtést illetően. 
Egyrészt a kutatásban részt vevő személyek száma rendkívül alacsony, nem elegendő ahhoz, hogy nagyobb populációra általánosítani lehessen. Ehhez további adatfelvételre lenne szükség. Másrészt, az általam használt tulajdonságlista nem biztos, hogy fedte az agresszió megnyilvánulási formáit. Eredeti szándékom az volt, hogy a történet után megítéltetett jellemzők ne torzítsák a diákok történetről szőtt attribúcióit, ezért nem tartottam helyesnek, ha közvetlenül rákérdezek, mennyire tartják agresszívnek Máriát, illetve Bélát. Utólag hibának vélem, hiszen a veszekedős, a barátságtalan, az idegesítő, a hideg, a felelötlen, a modortalan és a beképzelt tulajdonságok nem fedik az agressziót, viszont vizsgálni lehetett volna, mennyire járnak együtt az agresszív jelzővel. A tulajdonságlista más szempontból is kifogásolható, hiszen túl sok jellemzőt ítéltettem meg a diákokkal. A sztereotípiák feltérképezésének szándéka állt ennek hátterében, de a faktoranalízis nem hozta meg a kívánt eredményt, és ezzel talán felületes, nem átgondolt válaszadást értem el. A faktoranalízis alkalmazásakor minél nagyobb a mintanagyság, annál megbízhatóbb faktorokat eredményez az elemzés, vagyis a kis elemszám kisebb megbízhatóságot eredményezett. Azonban szükséges volt ezen struktúra-feltáró módszer alkalmazása, hiszen nem voltak előre meghatározott függő és független változók, hanem a változók közötti összefüggések feltárására törekedtem.

Azt a hipotézisemet, hogy a bűnözőkről alkotott sztereotípiák szerint a bünelkövetők inkább agresszívek, mint az átlagos emberek, csak részben sikerült alátámasztanom. A büntetett előéletűeket felelőtlenebbnek, modortalanabbnak és veszekedősebbnek tartják, mint a büntetlen személyeket, de a korrelációs kapcsolatok vizsgálatával megállapított további jellemzők tekintetében nem találtam szignifikáns eltérést a két csoport között. Ezt szintén okozhatták a fent vázolt problémák.

Vizsgálatom azt igazolta, hogy a személypercepció, vagyis a különböző személyiségvonások és viselkedés-értelmezések szempontjából a megítélt személy büntetett előéletéből fakadó sztereotípiáknak nagyobb a hatása, mint a neméből származóknak. Ezt okozhatja az is, hogy a diákok rendelkeznek saját tapasztalatokkal a nemi sztereotípiákat illetően, de nincsenek valós, kézzelfogható élményeik az elítéltekkel kapcsolatban, ezért csak a sztereotípiákra támaszkodhatnak. Egyes vizsgálatok (Atkinson 2005) arra utalnak, hogy a különböző társadalmi csoportok tagjai közötti strukturált együttműködésen alapuló kapcsolatok csökkentik a sztereotipizálást, és elősegítik az individualizációt, mert így pontos, személyre szabott benyomásokat szerezhetnek a másik csoportról. Már pusztán a sztereotípiák észlelésünket és cselekedeteinket torzító jellegének felismerése elegendő lehet a sztereotípiák felülírásának igényéhez.

Semin és Fiedler (1992) nyelvi kategóriák modelljét részben sikerült csak igazolnom. Az általam kitalált történetben csak leíró igék szerepeltek, de a vizsgálati 
személyeknek lehetőségük volt a konkrét-absztrakt dimenzió különböző pontjain elhelyezkedő nyelvi eszközökkel kifejezni az állítmányt. A diákok az agresszív epizód során használtak leggyakrabban absztraktabb megfogalmazást, ez legerősebben a büntetett előéletű férfiaknál jelent meg, de hasonlóan magas volt az absztrakciós szint a büntetlen férfiaknál és a büntetett nőknél egyaránt. A proszociális és a gondoskodó epizódot ennél lényegesen konkrétabban fogalmazták meg. Ennek az lehet az oka, hogy e közül a három viselkedés közül az agresszió váltja ki a leghevesebb indulatokat. Az absztrakciós szint azonban sehol nem haladta meg az 1,83-at, vagyis többségében leíró igéket alkalmaztak a történet felelevenítésekor.

Ennek egyik lehetséges oka az, hogy az általam készített rövid történethez túlzottan ragaszkodtak, vagy nem sikerült eléggé kétértelművé tennem az egyes epizódokat, hadd döntsék el ők, hogy szituatív vagy vonásbeli okokra vezetik vissza a fiktív személy viselkedését.

Az, hogy a vizsgálatommal nem, illetve csak részben sikerült bizonyítanom a nemi és a büntetett előéletű személyekkel szemben támasztott sztereotípiák létezését, pozitívumként is felfogható. Ahogy a társadalom tagjai egyre több információval rendelkeznek egymásról, csökken a körükben az előítéletesség.

\section{IRODALOM}

Antal Zsolt (2008): A médiatartalom kvantitativ és kvalitativ mérési és elemzési metodikája, alkalmazott médiaanalizis.

Interneten: http://tulipan.vjk.ppke.hu/modul/mcs124_Gazs\%f3Tibor.doc (2008. 03. 16.) Atkinson, Hilgard (2005): Pszichológia. Budapest: Osiris.

Banaji, Mahzarin (2003): Implicit sztereotipizálás a személyekről alkotott ítéletekben. In uő.: Rejtözködö attitüdök és sztereotípiák. Budapest: Osiris.

Bartlett, Frederic Charles (1985): Az emlékezés - Kisérleti és szocálpszichológiai tanulmány. Budapest: Gondolat.

Fehér Lenke (1999): Bủnözés, áldozattá válás, prostitúció. In Pongrácz Tiborné és Tóth István György (szerk.): Szerepváltozások. Jelentés a nök és férfiak helyzetéröl. Budapest: TÁRKI, Szociális és Családügyi Minisztérium.

Maass, Anne, Daniela Salvi, Luciano Arcuri andGun R. Semin (1989): Language Use in Intergroup Contexts. The Linguistic Intergroup Bias In Journal of Personality and Social Psychology, 57 (6): 981-993.

Semin, Gün R. and Klaus Fiedler 1992. The inferential properties of interpersonal verbs. In Gün R. Semin and Klaus Fiedler (szerk.): Language, interaction and social cognition. London: Sage, 58-78.

Smith, Eliot R. és Dian Mackie (2006): Szociálpszichológia. Budapest: Osiris. 